ABDIMAS: Jurnal Pengabdian Masyarakat Universitas Merdeka Malang
Vol.6(1) February 2021, 27-34
L-ISSN: 2721-138X e-ISSN: 2548-7159
Uttp://jurnal.unmer.ac.id/index.php/jpkm

\title{
Pendampingan Perencanaan Mix Mode Hemat Energi pada Rumah Baca Supiturang, Kecamatan Karangploso, Kabupaten Malang
}

\author{
Cynthia Permata Dewi, Apif Miptahul Hajji, Imam Alifianto \\ DepartemenTeknik Sipil, Fakultas Teknik, Universitas Negeri Malang \\ Jl. Semarang No.5 Malang, 65145, Indonesia
}

\author{
ARTICLE INFO \\ Received: 2020-11-06 \\ Revised: 2020-12-25 \\ Accepted: 2021-01-16 \\ Keywords: \\ Artificial lighting, \\ Natural lighting, \\ Simulation
}

\begin{abstract}
Lighting strategy in a building play important role, especially for building with specific function like a small community library in Supiturang. An appropriate lighting design will help user inside the building doing their activities comfortably. The daylight as the primary source of lighting in a building which also can save electricity energy should utilized well. This paper promotes the use of mix model lighting strategies between natural and artificial lighting in order to reach visual comfort inside the building. Department of Civil Engineering, Faculty of Engineering, State University of Malang take place as an academics to share knowledge in the society in Supiturang village. The mixed used design of natural and artificial design strategy was used to save electricity energy in building and optimize the visual comfort for reading activities. Methods that used in this community service activity were interview, field survey to get building physical data and simulation of lighting design. During the covid-19 situation, in the beginning there was a problem in executing this activity. Since the policy on the village was not allowing to gather many people in the small community library, of Supiturang village, thus the proposed design was only explained to the head of the Supiturang village as the policy holders.
\end{abstract}

(C) 2021 Published by University of Merdeka Malang. This is an open access article distributed under the CC BY-SA 4.0 license (https://creativecommons.org/licenses/by-sa/4.0/)

How to cite: Dewi, C. P., Hajji, A. M., \& Alifianto, I. (2020). Pendampingan Perencanaan Mix Mode Hemat Energi pada Rumah Baca Supiturang, Kecamatan Karangploso, Kabupaten Malang. Abdimas: Jurnal Pengabdian Masyarakat Universitas Merdeka Malang, 5(3), 27-34. https://doi.org/10.26905/abdimas.v6i1.4995

\section{PENDAHULUAN}

Strategi pencahayaan pada bangunan umumnya ada dua jenis, yang pertama adalah pencahayaan alami, dan yang kedua adalah pencahayaan buatan. Untuk pencahayaan alami yang tergantung pada desain elemen bukaan dalam hal ini jendela, sampai saat ini masih belum masuk ke tahapan desain sebuah bangunan. Dengan kata lain, jendela hanyalah sebagai elemen yang "syukur ada" atau tidak dirancang khusus untuk memenuhi tingkat pencahayaan tertentu yang dibutuhkan pada bangunan. Salah satu fungsi utama pencahayaan sebagai penjamin keselamatan pengguna interior dari sisi kenyamanan visual menjadi hal yang sering diabaikan (Dora \& Nilasari, 2011). 
ABDIMAS: Jurnal Pengabdian Masyarakat Universitas Merdeka Malang Volume 6, No. 1, February 2021: 27-34

Posisi indonesia yang berada pada wilayah tropis cenderung membawa cahaya masuk ke dalam ruang bersama radiasi panas matahari (Thojib \& Adhitama, 2013). Disisi lain, keberadaan elemen peneduh (solar shading) menjadi salah satu hal lain yang harus diperhatikan (Dewi et al., 2019). Potensi pencahayaan alami pada bangunan seringkali tidak dimanfaatkan secara optimal (Kurniasih \& Saputra, 2019)

Penggunaan pencahayaan alami sebagai sumber penerangan dalam aktivitas dalam ruangan memiliki beberapa kekurangan (Pangestu, 2019), antara lain: kuat terang cahaya tidak dapat diatur dengan flexible sehingga bisa jadi sangat terang (menyilaukan) atau bisa jadi sangat redup, cahaya matahari yang masuk ke dalam ruangan membawa radiasi panas sehingga dapat mempengaruhi kenyamanan termal dalam hunian, kemudian untuk bangunan dengan jumlah lantai yang cukup banyak ataupun 'bulky' maka pencahayaan alami akan sulit masuk ke dalam ruang.

Untuk pencahayaan buatan, terdapat beberapa jenis teknik pencahayaan buatan, antara lain: direct lighting dan indirect lighting (Setiawan \& Hartanti, 2014). Berdasarkan SNI 2000 (Badan Standardisasi Nasional, 2000), yang mengatur tentang standar pencahayaan dalam ruang, minimal tingkat lux untuk area membaca adalah 300 lux dengan temperature warna cool white. Faktor-faktor lain yang mempengaruhi tingkat pencahayaan dan kuat penerangan dalam ruang antara lain orientasi, posisi, jumlah, bentuk dan dimensi bukaan.

Supiturang merupakan salah satu dusun yang berada di wilayah Desa Bocek, kecamatan Karangploso, Kabupaten Malang. kondisi topografi pada dusun Supiturang ini merupakan dataran sedang dengan ketinggian sekitar $700 \mathrm{~m}$ di atas permukaan laut. Lokasi pengabdian ini berada dalam radius sekitar 16,5 km dari Universitas Negeri Malang. Terkait dengan kondisi masyarakatnya, di dusun Supituang ini setiap tahun terus mengalami kemajuan. Salah satunya ada akses jalan. Infrastuktur jalan raya pada kawasan ini berkembang cukup baik dengan penggunaan lapisan aspal sebagai pengganti jalan tanah.

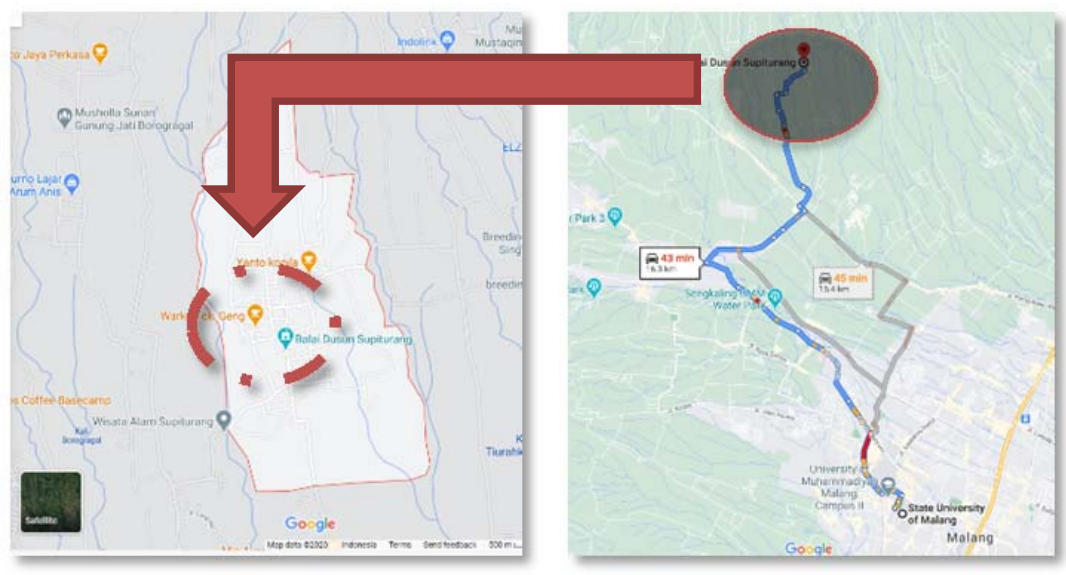

Gambar 1. Lokasi pengabdian balai Desa Supiturang, Kecamatan Karangploso, Kabupaten Malang 


\section{Pendampingan Perencanaan Mix Mode Hemat Energi pada Rumah Baca Supiturang, Kecamatan Karangploso... \\ Cynthia Permata Dewi, Apif Miptahul Hajji, Imam Alifianto}

Sarana prasarana Gedung yang ada adalah balai desa. Kesadaran masyarakat akan pentingnya pendidikan sudah mulai meningkat. Tingkat pendidikan warga juga sudah lebih tinggi dibandingkan sebelumnya. Bahkan sudah terdapat fasilitas rumah baca yang dikelola secara swadaya oleh masyarakat. Namun demikian, pada saat dilakukan survei lokasi, buku-buku bacan yang disediakan dalam kondisi yang kurang layak sehingga perlu diperbarui untuk menungjang kegiatan rumah baca ini.

Rumah baca supit urang ini memanfaatkan balai desa sebagai tempak aktivitas warga termasuk untuk sarana rumah baca. Anak-anak di dusun supiturang ini banyak memanfaatkan fasilitas baca yang disediakan pada rumah baca ini. Namun, selama periode pandemi covid-19 ini, pemanfaatan balai desa dibatasi penggunaannya. Balai desa hanya dimanfaatkan pada saat-saat tertentu saja yang krusial, missal saat posyandu, sehingga anak-anak yang memanfaatkan fungsi rumah baca ini sangat terbatas waktunya. Desain jendela pada rumbah baca ini tidak dapat memaksimalkan cahaya matahari yang masuk ke dalam ruangan (Kalinkina et al., 2020). Serta minimnya pencahayaan buatan pada rumah baca ini sehingga, jika kondisi langit mendung atau malam hari pun pengguna rumah baca ini kurang nyaman dalam melakukan aktivitas.

Sama halnya yang dialami oleh Masyarakat Desa Supiturang, Kabupaten Malang. Keberadaan balai desa sebagai sarana bersama untuk memfasilitasi kegiatan warga, salah satunya dimanfaatkan sebagai rumah baca. Desain bangunan rumah baca ini memilikijendela di sisi bagian depan dan sampin bangunan. Namun demikian, tidak serta merta menjadikan bangunan ini maksimal pencahayaan alaminya. Tetapi masih membutuhkan bantuan pencahayaan buatan (lampu). Kondisi aktual di lapangan, hanya terdapat satu titik lampu untuk bangunan ini, sehingga bagaimanapun aktivitas membaca sangat kurang sekali tingkat pencahayaan yang cukup dalam memenuhi kenyamanan visual untuk aktivitas tersebut. Bahkan untuk kegiatan yang dilakukan warga pada malam hari sangat tidak nyaman karena tingkat penerangan yang sangat kurang dengan ketersediaan hanya satu buah lampu pada ruangan tersebut. Hal ini sesuai dengan studi yang dilakukan oleh Samani \& Samani, yang menyatakan bahwa pencahayaan dalam ruang sangat penting dan dapat mempengaruhi kinerja pengguna bangunan (Samani \& Samani, 2012).

\section{METODE}

Pengabdian masyarakat ini menggunakan penerapan simulasi ipteks. Penggunaan simulasi ipteks disini adalah untuk mencapai tujuan memberikan pengarahan, masukan atau saran kepada masyarakat Desa Supiturang khususnya terkait dengan teknologi pencahayaan yang hemat energi dengan adanya kombinasi atau perpaduan dari penggunaan strategi pencahayaan pencahayaan alami dengan pencahayaan buatan. Strategi ini dipilih, mengingat fungsi bangunan yang digunakan tidak hanya pada siang hari, namun juga sore-malam hari, dimana fungsi pencahayaan alami pada waktu-waktu tersebut tidak dapat optimal sehingga harus menggunakan bantuan pencahayaan buatan (Christoffersen, 2011). Lebih lanjut lagi, penggunaan mix mode atau kombinasi teknik pencahayaan alami dan buatan pada bangunan dapat saling mengisi kelemahan masing-masing teknik, dimana pencahayaan alami memiliki kelemahan dalam mengatur silau yang mungkin terjadi pada bangunan (Sharaf, 2014). Hasil rekomendasi dari simulasi ipteks ini kemudian diserahkan keapada pihak desa untuk masuk ke dokumen perencanaan perbaikan balai desa. 
ABDIMAS: Jurnal Pengabdian Masyarakat Universitas Merdeka Malang

Volume 6, No. 1, February 2021: 27-34

Kegiatan ini dimulai dengan survei lokasi terlebih dahulu untuk mengecek kondisi bangunan dan lingkungan terlebih dahulu. Kegiatan pengabdian sempat tertunda karena kondisi COVID-19 yang menyebabkan adanya kebijakan untuk meniadakan sementara kegiatan yang menggunakan lokasi rumah baca. Pengambilan data dilakukan dengan melakukan izin terlebih dahulu kepada kepala desa. Pengambilan data berupa pengukuran fisik bangunan dilakukan menggunakan meteran manual. Untuk pengambilan data tingkat pencahayaan dilakukan dengan penggunaan lux meter.
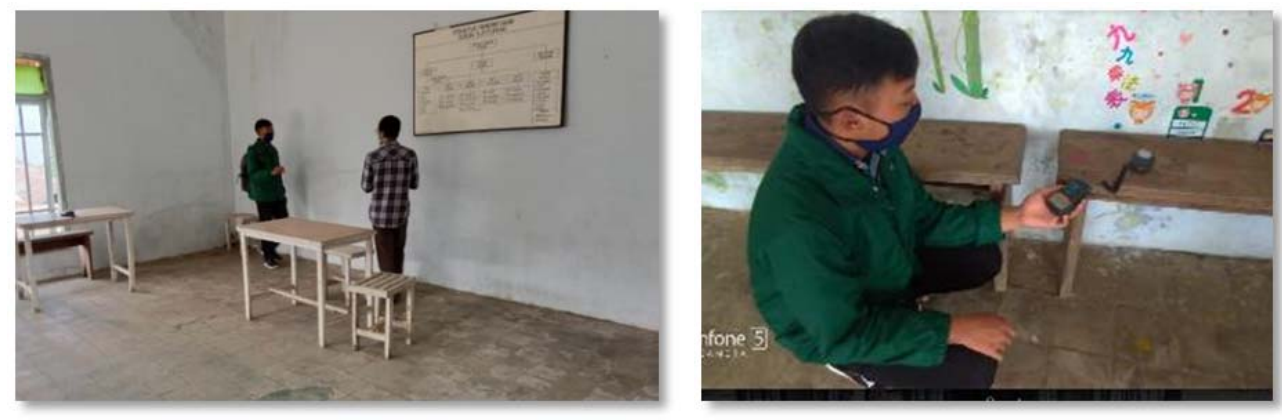

Gambar 2. Pengambilan data fisik bangunan

Gambar 3. Pengambilan data tingkat pencahayaan dengan lux meter

Setelah memperoleh data yang diperlukan baik fisik, maupun data tingkat pencahayaan. Tahapan berikutnya adalah membuat model fisik bangunan dan model simulasi untuk keperluan simulasi pencahayaan. Model fisik bangunan dibuat untuk eksisting model dan alternative model yang sudah dimodifikasi dengan menambahkan bukaan pada sisi bangunan sebelah selatan.

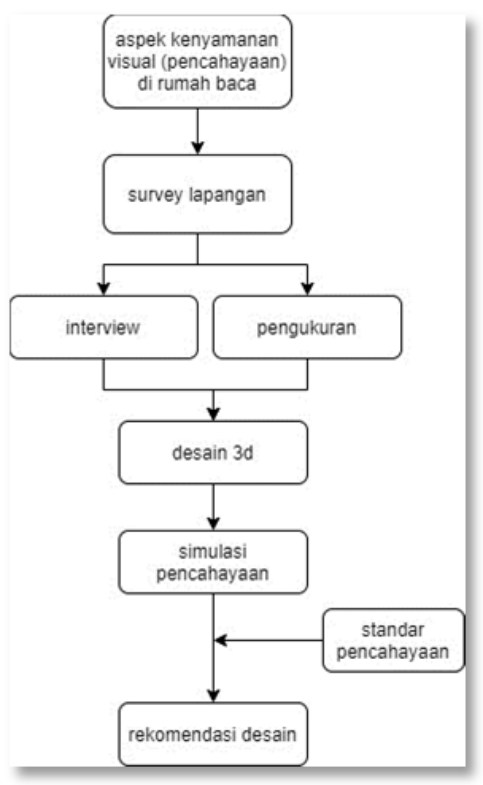

Gambar 4. Diagram alur kegiatan pengabdian 


\section{HASIL DAN PEMBAHASAN}

Dalam tahapan analisis yang dilakukan adalah dengan mengetahui kondisi aktual tingkat pencahayaan pada bangunan eksisting. Pengukuran lapangan yang dilakukan pada titik-titik tertentu menunjukkan hasil yang sama dengan hasil simulasi komputer. Beberapa titik yang dilakukan pengukuran dan pegamatan adalah area sekitar jendela di sebelah selatan bangunan dan area sekitar ruang baca.
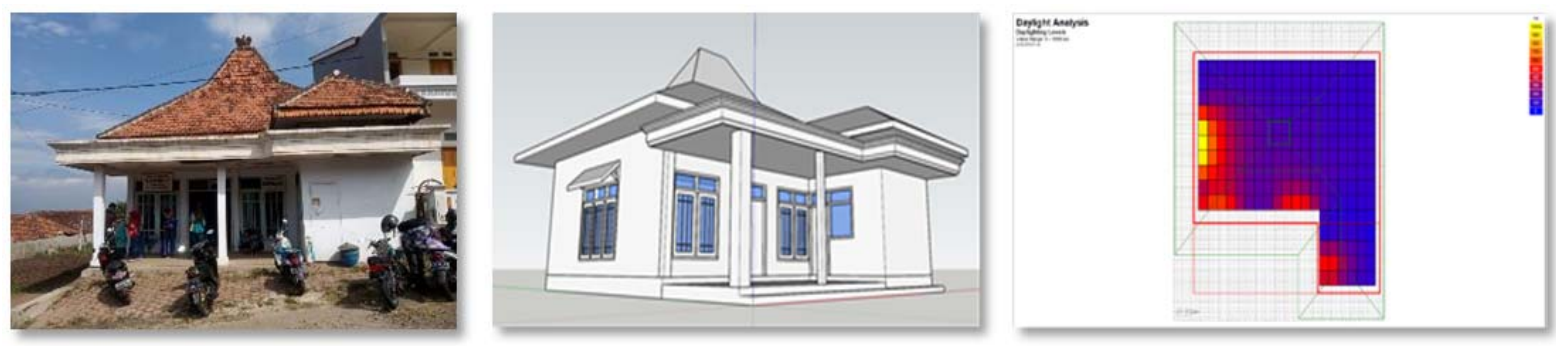

Gambar 5. Foto rumah baca di Balai Desa Supiturang

Gambar 6. Model 3D eksisting

Gambar 7. Hasil simulasi pencahayaan alami

Gambar 7 merupakan hasil simulasi untuk kondisi eksisting bangunan. Dari hasil simulasi dapat dilihat bahwa tingkat pencahayaan di rumah baca balai Desa Supiturang masih sangat kurang. Hal ini dapat dilihat bahwa area biru yang berarti tingkat pencahayaan berkisar antara 0-100 lux adalah lebih dari $50 \%$ luas area rumah baca. Seperti halya dengan studi pencahayaan yang dilakukan oleh beberapa orang sebelumnya, tingkat pencahayaan yang disarankan untuk ruang perpustakaan atau yang berhubungan dengan kegiatan membaca adalah minimal 300 lux (Roy et al., 2018)

Area baca pada ketinggian $80 \mathrm{~cm}$ tidak memenuhi persyaratan minimal lux untuk kegiatan membaca. Hal ini dikarenakan jendela sebagai satu-satunya sumber pencahayaan alami pada bangunan tidak maksimal karena pada area sisi selatan bangunan hanya terdapat satu unit jendela. Kondisi aktual untuk pencahayaan buatan juga sangat minim. Hanya ada satu lampu di ruangan tersebut. jenis compact fluorescent lamp. Dari hasil pengukuran dan analisis kondisi eksisting, maka dilakukan redesain terhadap desain pencahayaan alami dan pencahayaan buatan.


Gambar 8. Kondisi pencahayaan buatan pada bangunan eksisting rumah baca

Gambar 9. Redesain pencahayaan alami

Gambar 10. Hasil simulasi alternatif desain pencahayaan alami 
ABDIMAS: Jurnal Pengabdian Masyarakat Universitas Merdeka Malang Volume 6, No. 1, February 2021: 27-34
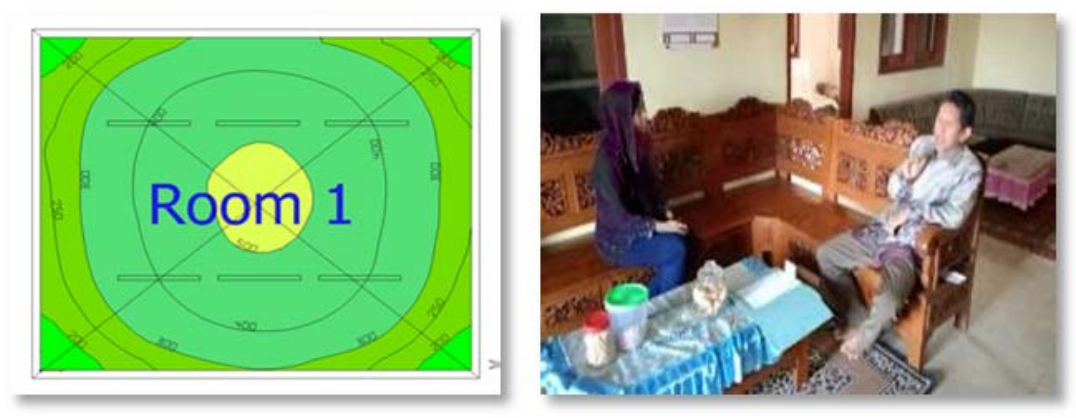

Gambar 11. Hasil simulasi pencahayaan buatan LED TI

Gambar 12. Diskusi dan penyampaian hasil pengabdian dengan kepala desa

Setelah dilakukan pengukuran dan simulasi untuk kondisi bangunan eksisting, maka diperlukan penambahan bukaan sehingga dapat mengoptimalkan cahaya matahari masuk ke dalam ruangan. Untuk redesain pencahayaan alami, diusulkan untuk menambahkan jendela sebagai sarana untuk memasukkan cahaya matahari ke dalam ruangan. Penambahan dua jendela dengan desain yang sama persis dengan jendela sebelumnya sehingga membuat bangunan ini memiliki ritme desain jendela yang sama. Hasil simulasi untuk alternatif pencahayaan alami pada Gambar 10 menunjukkan tingkat pencahayaan alami pada ruang dengan kondisi terang langit yang sama dengan kondisi eksisting menunjukkan perubahan yang cukup signifikan. Pada area pengamatan, tingkat pencahayaan berkisar 500 lux, sehingga memenuhi standar tingkat pencahayaan untuk fungsi ruang baca dalam ruangan.

Mixed desain dengan sistem pencahayaan buatan menggunakan sistem grid LED TI 3x2 LED 24watt seperti pada gambar Gambar 11. Hasil simulasi desain pencahayaan buatan menunjukkan bahwa $80 \%$ ruangan terpenuhi kebutuhan tingkat pencahayaannya. Dengan demikian maka penambahan bukaan jendela dengan dimensi $1.5 \times 2$ m dan penggunaan TI LED 24-watt yang dipasang secara grid $3 \times 2$ merupakan alternatif desain mix mode pencahayaan alami dan buatan yang optimal pada fungsi rumah baca di balai Desa Supiturang.

Hasil luaran yang disampaikan lebih mudah dilakukan dengan membuat gambar 3D dan penjelasan tertulis yang akan dibuat dalam bentuk laporan dan gambar desain sehingga dapat dijadikan acuan oleh masyarakat desan Supiturang yang memiliki visi dalam melakukan renovasi terhadap Gedung balai desa yang memfasilitasi berbagai macam aktivitas warga. Dengan demikian warga Desa Supiturang ke depannya bisa memiliki fasilitas yang nyaman pada berbagai macam kegiatan yang diselenggarakan, khususnya juga sebagai sarana rumah baca.

\section{SIMPULAN DAN SARAN}

\section{Simpulan}

Dari rangkaian kegiatan pengabdian masyarakat yang sudah dilakukan dapat ditarik beberapa simpulan dan saran, antara lain: (1) Kegiatan pengabdian masyarakat yang dilakukan dapat memberikan 
pengetahuan terhadapat masyarakat terkait khususnya masyarakat Desa Supiturang tentang standarstandar minimal tingkat pencahayaan dalam ruangan untuk fungsi baca; (2) Masyarakat Desa Supiturang khususnya memiliki pengetahuan bahwa fungsi jendela sebagai sarana memasukkan pencahayaan alami sangat penting mendapatkan perhatian; dan (3) Hasil diskusi dengan kepala desa, bahwa kedepannya diharapkan balai desa yang memfasilitasi kegiatan warga tersebut dapat direnovasi sehingga dapat lebih baik lagi dalam memfasilitasi kegiatan warga.

\section{Saran}

Untuk kegiatan pengabdian masyarakat ke depannya dapat dilakukan dengan membuat rencana desain apabila bangunan dikembangkan menjadi dua lantai sesuai dengan visi Desa Supiturang, rancangan renovasi sebaiknya mempertimbangkan semua aspek desain, sehingga dalam beroperasi nantinya bisa berjalan maksimal dengan desain bangunan sendiri.

\section{DAFTAR PUSTAKA}

Badan Standardisasi Nasional. (2000). Konservasi energi pada sistem pencahayaan. SNI 03-61972000.

Christoffersen, J. (2011). The importance of light to health and well-being. In Proceedings of the 4th VELUX Daylight Symposium "Daylight in a Human Perspective", Lausanne, Switzerland.

Dewi, C. P., Utomo, J. B., \& Choirotin, I. (2019). Optimalisasi kinerja solar shading sebagai usaha menurunkan solar gain pada bangunan. RUAS (Review of Urbanism and Architectural Studies), 16(2), 42-48.

Dora, P. E., \& Nilasari, P. F. (2011). Pemanfaatan Pencahayaan Alami pada Rumah Tinggal Tipe Townhouse di Surabaya. Dalam Seminar Nasional Living Green: Mensinergikan Kehidupan, Mewujudkan Keberlanjutan, 26 Mei 2011, Universitas Kristen Petra.

Kalinkina, N., Zhdanova, I., \& Chernysheva, I. (2020). The organization of natural lighting in buildings with difficult illuminated areas. Dalam /OP Conference Series: Materials Science and Engineering 753(3), 032009. IOP Publishing. https://doi.org/10.1088/1757-899X/753/3/032009

Kurniasih, S., \& Saputra, O. (2019). Evaluasi tingkat pencahayaan ruang baca pada perpustakaan Universitas Budi Luhur, Jakarta. Jurnal Arsitektur ARCADE, 3(1), 73-79.

https://doi.org/10.31848/arcade.v3i1.136

Pangestu, M. D. (2019). Pencahayaan Alami pada Bangunan. Unpar Press.

Roy, M., Hamzah, B., \& Jamala, N. (2018). Analisis pencahayaan alami ruang perpustakaan Fakultas Teknik Gowa Universitas Hasanuddin. Jurnal Lingkungan Binaan Indonesia, 7(2), 111-115. https://doi.org/10.32315/jlbi.7.2.111

Samani, S. A., \& Samani, S. A. (2012). The impact of indoor lighting on students' learning performance in learning environments: A knowledge internalization perspective. International Journal of Business and Social Science, 3(24).

Setiawan, B., \& Hartanti, G. (2014). Pencahayaan buatan pada pendekatan teknis dan estetis untuk bangunan dan ruang dalam. Humaniora, 5(2), 1222-1233.

https://doi.org/10.21512/humaniora.v5i2.3265 
ABDIMAS: Jurnal Pengabdian Masyarakat Universitas Merdeka Malang Volume 6, No. 1, February 2021: 27-34

Sharaf, F. M. (2014). Daylighting: An alternative approach to lighting buildings. Journal of American Science, 10(4), 1-5.

Thojib, J., \& Adhitama, M. S. (2014). Kenyamanan visual melalui pencahayaan alami pada kantor (Studi kasus Gedung Dekanat Fakultas Teknik Universitas Brawijaya Malang). RUAS (Review of Urbanism and Architectural Studies), 11(2), 10-15. http://dx.doi.org/10.21776/ub.ruas.2013.011.02.2 